\title{
THE PERFORMANCE DIFFERENCES BETWEEN HIGH AND LOW SALES TURNOVER COMMUNITY PHARMACIES
}

\author{
Perbedaan Performa Apotek Omzet Tinggi dan Apotek Omzet Rendah \\ *Ni Putu Udayana Antari ${ }^{1}$, Ni Putu Dewi Agustini ${ }^{1}$, Ni Made Dharma Shantini Suena ${ }^{1}$ \\ ${ }^{1}$ Faculty of Pharmacy, Universitas Mahasaraswati Denpasar, Indonesia \\ Correspondence*: \\ Address: Jln. Kamboja No.11 A Denpasar, Indonesia | e-mail: udayanaantari@unmas.ac.id
}

\begin{abstract}
Background: Pharmacy managers will make various efforts to increase their income. In spite of this, pharmacies that have the same facilities can generate greatly varied incomes.

Aims: The purpose of this study was to determine the difference between high sales turnover pharmacies and low sales turnover pharmacies as observed through employee motivation, organizational culture, and patient satisfaction.

Methods: This study used an analytical design with a questionnaire and checklist. Consumers were selected using the purposive sampling system to assess patient satisfaction. All employees were sampled to assess work motivation and organizational culture. Data analysis was performed using descriptive, bivariate, and multivariate testing.

Results: Direct observation of pharmaceutical services from the two outlets shows that there were differences in the time it takes for pharmacist to retrieve the drug, the time for providing drug information, collecting information from patients, and the type of drug information provided, as well as employee motivation, organizational culture, and patient satisfaction.

Conclusion: Services at pharmacies with high sales turnover are different from pharmacies with low sales turnover. Empathy has the greatest effect on sales turnover, followed by reliability, responsiveness, assurance, and tangible dimensions. Outlets that have high sales turnover have better organizational culture and higher employee motivation when compared to outlets that have low sales turnover.
\end{abstract}

Keywords: motivation, organizational culture, patient satisfaction, sales turnover

\begin{abstract}
Abstrak
Latar Belakang: Berbagai upaya akan dilakukan oleh pengelola apotek untuk meningkatkan omzet. Walaupun demikian, apotek yang memiliki fasilitas sama dapat menghasilkan omzet yang jauh berbeda.

Tujuan: Penelitian ini mengidentifikasi perbedaan antara apotek yang beromzet tinggi dan apotek beromzet rendah yang dilihat pada motivasi kerja karyawan, budaya organisasi, dan kepuasan pasien.

Metode: Penelitian ini menggunakan desain analitik dengan instrumen kuesioner dan checklist. Sampel dari konsumen diambil dengan menggunakan sistem purposive sampling untuk menilai kepuasan pasien. Semua karyawan dijadikan sampel untuk menilai motivasi kerja dan budaya organisasi. Analisis data dilakukan dengan pengujian deskriptif, bivariat, dan multivariat.

Hasil: Pengamatan langsung pelayanan kefarmasian dari kedua outlet menunjukkan adanya perbedaan waktu penyiapan obat, waktu pemberian informasi obat, pengumpulan informasi dari pasien, jenis informasi obat yang diberikan, serta motivasi pegawai, budaya organisasi dan kepuasan pasien.

Kesimpulan: Pelayanan kefarmasian di apotek dengan omset tinggi berbeda dengan apotek dengan omset rendah. Empati memiliki pengaruh terbesar pada omzet, kemudian dimensi kehandalan, daya tanggap, jaminan, dan fasilitas fisik/ tangible. Outlet yang memiliki omzet tinggi memiliki budaya organisasi yang lebih baik dan motivasi karyawan yang lebih tinggi jika dibandingkan dengan outlet yang memiliki omzet rendah.
\end{abstract}

Kata kunci: budaya organisasi, kepuasan pasien, motivasi, omzet 


\section{Introduction}

In many countries, health reform has been an ongoing agenda (Hermansyah, Sainsbury and Krass, 2018). Pharmacist in Indonesia is crucially need to change the current pharmacy practice (Athiyah et al., 2019). In order to create a more professional climate for the pharmacy practice, some fundamental and entrenched barriers to practice will need to be overcome in Indonesia (Hermansyah, Sainsbury and Krass, 2018). Several challenges are hampering the sustainability of pharmacy services delivery in the setting of primary care (Hermansyah et al., 2020). Therefore the need to strenghthen pharmacy competitiveness is pivotal.

Pharmacies, as places of service for the pharmacist profession, have a social function as well as a business function. The tight competition, changes in consumer tastes, technological advances, and socio-economic changes also require pharmacies to make more improvements in order to carry out both business and social functions properly. The social function of a pharmacy cannot run well without the support of a smooth business function. One of the measuring tools for the success of a pharmacy in carrying out its business functions is the amount of sales turnover. Sales turnover is the total amount of goods or services sales within a certain period, which is calculated based on the amount of money earned and by the volume of goods (Rizal, Romidon and Handika, 2017). There are strong positive relationship between total sales, company efficiency and profitability (Alarussi and Alhaderi, 2018; Nasution, 2020).

Employees in community pharmacies play a far significant and distinct role compared to the employees in traditional retail stores. Employee performance of community pharmacies influence customer loyality (Rabbanee, Burford and Ramaseshan, 2015). Trust in pharmacists leads to satisfaction and finally affect the store loyalty (Castaldo et al., 2016; Nitadpakorn, Farris and Kittisopee, 2017). Loyalty will increase along sales advocacy and improve pharmacy competitiveness (Dung, 2019). Pharmacies run and managed by qualified pharmacists play an important role in good pharmaceutical service and rational drug use (Jawaid, 2016), also significanly enhance health-care outcomes and patient's quality of life (Kristina, Lienaningrum and Aditama, 2021).

The function of Pharmacy dominantly shift to business orientation (Novianita, Sutarsa and Adiputra, 2016). It is necessary to be conscious of the factors that affect the success of pharmacies as business units in order for pharmacy owners to maintain their pharmacies' growth as business units.

Most of the existing studies explain the influence of internal factors on the social side of pharmaceutical services, such as customer satisfaction, customer loyalty, quality of pharmacies, (Nitadpakorn, Farris and Kittisopee, 2017; Dung, 2019; Salem et al., 2020). According to the author's studies on various relevant original articles, there has been no research that explains the factors that directly influence pharmacy sales turnover as an indicator of business success. This study aims to determine the factors that affect pharmacy sales turnover, assuming the pharmacies included in this study have the same facilities and management standards. Factors studied include patient satisfaction, employee work motivation, and organizational culture. Direct observations of pharmaceutical services were carried out to conduct a comparison of pharmaceutical services in each outlet. Thus, the research results can be a reference for pharmacy managers to increase sales turnover through improved pharmaceutical services and better human resource management.

One of the pharmacy networks in the Nusa Dua area divides its outlets into four class classifications, namely classes $1,2,3$, and 4 . The classes are classified based on the sales turnover achieved by each pharmacy. Pharmacy class 1 (one) refers to pharmacies that produce high sales turnover, followed by pharmacy class 2 (two), pharmacy class 3 (three), and pharmacy class 4 (four). Pharmacy 
class 4 (four) refers to pharmacies with low sales turnover or newly established pharmacies. The pharmacy network has a standard management system that is implemented by all outlets (Athiyah et al., 2019). Outlet 1 in this research classified to class 1 (high sales turnover) outlet 2 in this research classified to class 3 (low sales turnover) eventhough both the outlet have the same facilities. This shows that there are other factors outside of standard facilities and management that affect the sales turnover.

\section{Method}

This study was conducted with a cross-sectional method. The data were collected by distributing questionnaires and direct observation. Direct observation was carried out using passive participation observation methods. The research was carried out at outlet 1 and outlet 2 of the pharmacy network in the Nusa Dua area from April 2019 to May 2019. Outlet 1 was categorized as a class 1 pharmacy (high sales turnover) and outlet 2 was considered a class 3 pharmacy (low sales turnover). Both pharmacies had the same management standards and facilities, including equally large parking areas, accessible locations, open 24 (twentyfour) hours, and doctor's offices available.

The population of this study was consumers and employees of outlet 1 and outlet 2. The patient group sample consisted of 50 consumers who buy at outlet 1 and 50 consumers who buy at outlet 2. The pharmacy consumers sample for the patient satisfaction assessment was taken by using the purposive sampling technique based on predetermined inclusion and exclusion criteria. Firstly, the sample consisted of the consumers at outlet 1 or outlet 2 . Secondly, the sample had to be Indonesian citizen. Lastly, the sample had to be at least 18 years old. The exclusion criteria were the consumers that refused to become respondents and the consumers that did not fill in the questionnaire completely.

Samples were taken with accidental sampling in a direct observation. A total of 50 pharmaceutical services were observed at outlet 1, and 50 pharmaceutical services were observed at outlet 2. The observed pharmaceutical services included self-medication and prescription services, including both concocted prescriptions and nonconcocted prescriptions.

Employee samples were taken using the saturated sampling technique. The subjects of this study were all employees who agreed to join this study. In this study, all employees at both outlets agreed to be samples and participated until the research was completed. All respondents in this study agreed to participate after being provided with information and signing the informed consent form.

The instruments used in this study included, firstly, the questionnaire to assess patient satisfaction. This questionnaire referred to the ServQual method developed by Parasuraman, Zeithaml and Berry, (1988). Patient satisfaction could be seen from the gap or ServQual score. ServQual score = perception-expectation. The instrument consisted of an assessment of the patient's expectations and perceptions in five dimensions: tangibility, responsiveness, reliability, empathy, and assurance (Antari, Purnomo and Sumarni, 2011). The questionnaire was designed in the form of a closed-answer statement using a Likert scale.

Secondly, the questionnaire to assess employee motivation and organizational culture was used. The questionnaires for employee motivation and organizational culture assessment were adapted from Anwarudin's research (Anwarudin, Fudholi and Satibi, 2013). The questionnaire was made in a closed form using a Likert scale. The dimensions of evaluating employee work motivation include: trust in the institution, best performance at work, team spirit, and willingness to comply with roles. The dimensions of organizational culture are: good customer service, work priorities, planning, good communication, reward and punishment systems, problem solving, role implementation, time value, performance appraisal, responsibility, selfimprovement, and employee appreciation. 
Thirdly, the pharmaceutical service process observation form at the pharmacy was used. Observations on pharmaceutical services included the level of drug availability, the time it takes for pharmacists to retrieve the drugs, the duration of time for information administration, classification of patient information, and types of drug information provided.

All questionnaires used had been tested for validity and reliability using the one-shot method (one measurement). The validity test used was the Pearson Product Moment correlation technique. The reliability test was done by calculating the value of Cronbach Alpha.

Demographic data of respondents consisted of gender, age, most recent level of education, and observational data on the level of drug availability, duration of drug provision, classification of patient information, drug information administration, patient satisfaction, employee work motivation, and organizational culture were processed using descriptive statistics. Patient satisfaction was classified as very low, low, adequate, good, and very good. Employee work motivation and organizational culture were classified as bad, adequate, and good. Coding was done on qualitative data, then processed using appropriate statistical methods.

Patient satisfaction, employee motivation, and organizational culture were also tested using the bivariate test (Chi-square and Mann-Whitney test). A multivariate test (logistic regression) was used to determine the effect of each patient satisfaction dimension simultaneously. The test was conducted using the SPSS (Statistical Package for the Social Science) 21 with a confidence level of $95 \%$.

\section{Result and Discussion}

A direct observation aims to provide a descriptive description of pharmaceutical services atboth outlets. The data collected from outlet 1 consisted of 25 prescriptions (consisting of 4 concoction prescriptions and 21 non-concocted prescriptions) and 25 self-medicated transactions. The data collected from outlet 2 was the result of observations on 50 transactions consisting of 4 prescription transactions (only consisting of non-concocted prescriptions) and data on 46 self-medicated transactions. The data collected were similar for both outlet on the records of prescription receipts. The average prescriptions per month at outlet 1 were 300 prescriptions and the average prescriptions per month at outlet 2 were 20 prescriptions. Outlet 1 served more prescription exchanges than outlet 2 .

The level of drug availability from the observations at outlet 1 was as follows: 46 drugs available, 3 drugs need substitution, and 1 drug was not available. Based on the drug availability at outlet 2 , there were 49 available drugs and 1 substitution/copy drug.

Outlet 1 could provide faster services in terms of retrieving drugs and providing drug information (Table 1) However, the waiting time for services from the two outlets did not exceed the

Table 1. The Duration of Drug Handling Timing and Drug Information Administration

\begin{tabular}{lcccccc}
\hline \multicolumn{1}{c}{ Criteria } & \multicolumn{3}{c}{ Outlet 1 (Minute) } & \multicolumn{3}{c}{ Outlet 2 (Minute) } \\
\hline & $\begin{array}{c}\text { Fastest } \\
\text { timing }\end{array}$ & $\begin{array}{c}\text { Longest } \\
\text { timing }\end{array}$ & Average & $\begin{array}{c}\text { Fastest } \\
\text { timing }\end{array}$ & $\begin{array}{c}\text { Longest } \\
\text { timing }\end{array}$ & Average \\
\hline $\begin{array}{l}\text { Drug Handling Timing } \\
\text { Concocted prescriptions }\end{array}$ & 10 & 11 & 10.75 & - & - & - \\
$\quad \begin{array}{l}\text { Non-concocted prescriptions } \\
\text { Self-medication }\end{array}$ & $<1$ & 3 & 1.9 & 2 & 3 & 2.25 \\
Drug information administration & $<1$ & 2 & 1.04 & $<1$ & 3 & 1.3 \\
$\quad$ Concocted prescriptions & $<1$ & 2 & 1.3 & - & - & - \\
$\quad$ Non-concocted prescriptions & $<1$ & 1 & 1 & 1 & 2 & 1.25 \\
$\quad$ Self-medication & $<1$ & 1 & 1 & $<1$ & 2 & 1.08 \\
\hline
\end{tabular}


Table 2. Patient Information Classification and Drug Information Administration

\begin{tabular}{|c|c|c|c|}
\hline Criteria & Observational Points & Outlet 1 (\%) & Outlet $2(\%)$ \\
\hline \multirow{9}{*}{$\begin{array}{l}\text { Verification of } \\
\text { recipients of } \\
\text { prescriptions } \\
\text { and provision of } \\
\text { drug } \\
\text { information at } \\
\text { Prescription } \\
\text { services }\end{array}$} & 1. Calling the patient's name & $92.0^{*}$ & 75.0 \\
\hline & 2. Verify the patient & $28.0^{*}$ & 0.0 \\
\hline & 3. Information of types of drugs & 16.0 & $75.0^{*}$ \\
\hline & 4. Information of dosage & $16.0^{*}$ & 0.0 \\
\hline & 5. Information of the method of use & 64.0 & $75.0^{*}$ \\
\hline & 6. Information of the rules for using drugs & 96.0 & $100.0^{*}$ \\
\hline & 7. Information of drug side effects & 0.0 & 0.0 \\
\hline & 8. Information of drug storage methods & 24.0 & $25.0^{*}$ \\
\hline & 9. Non-pharmacological therapeutic information & 0.0 & 0.0 \\
\hline \multirow{9}{*}{$\begin{array}{l}\text { Classification of } \\
\text { patient } \\
\text { information in } \\
\text { self-medication } \\
\text { services }\end{array}$} & 1. Drug users & 92.0 & $100.0^{*}$ \\
\hline & 2. Age of user/patient & $32.0^{*}$ & 17.4 \\
\hline & 3. The gender of the user/patient & 0.0 & 0.0 \\
\hline & 4. Patient's weight & 0.0 & 0.0 \\
\hline & 5. Symptoms of the disease & 40.0 & $45.7^{*}$ \\
\hline & 6. Duration of disease symptoms & $92.0^{*}$ & 91.3 \\
\hline & 7. Take medication beforehand & $52.0^{*}$ & 4.3 \\
\hline & 8. Possible drug allergy & $52.0^{*}$ & 21.7 \\
\hline & $\begin{array}{l}\text { 9. The possibility of other diseases/special } \\
\text { circumstances }\end{array}$ & $12.0^{*}$ & 0.0 \\
\hline \multirow{7}{*}{$\begin{array}{l}\text { Providing drug } \\
\text { information at } \\
\text { self-medicated } \\
\text { services }\end{array}$} & 1. Information of the type of drug & $16.0^{*}$ & 8.7 \\
\hline & 2. Information of dosage & $12.0^{*}$ & 4.3 \\
\hline & 3. Information of method of use & $72.0^{*}$ & 34.8 \\
\hline & 4. Information of drug rules & 76.0 & $97.8^{*}$ \\
\hline & 5. Information of drug side effects & $76.0^{*}$ & 2.2 \\
\hline & 6. Information of drug storage methods & 28.0 & $37.0^{*}$ \\
\hline & 7. Non-pharmacological therapeutic information & 4.0 & $8.7^{*}$ \\
\hline
\end{tabular}

*Higher value for the related observational point

minimum standard set by the ministry of health, which is between $15-30$ minutes (Indonesian Ministry of Health, 2016). Similarly, a study at the Denpasar City Health Center has shown that the average waiting time for drug prescription services was $7.82 \pm 2.16$ minutes for concocted prescriptions and $4.01 \pm 1.75$ minutes for non-concocted prescriptions (Jaya and Apsari, 2018).

The results of the observations showed that there were some pieces of information that were rarely provided by pharmacists (frequency below 50\%) when delivering drugs, which consisted of both prescription and self-medicated services, including types of drugs, dosages, side effects of drugs, storage methods, and provision of non-pharmacological information. Outlet 1 got higher scores in 12 criteria, while outlet 2 got higher scores in 9 criteria of patient information classification and providing drug information (Table 2). According to Gunawan et al. (2011) and Made Novianita, Sutarsa and Adiputra, (2016), many observers consider that pharmaceutical services are still below standard. There needs to be increased awareness and engagement with quality and quality improvement efforts in the pharmaceutical sector (Watson and Skea, 2018). There are several possible reasons as to why some criteria of drug information are rarely provided when administering drugs. According to Satibi, Furdiyanti and Rahmawati, (2007), there were obstacles that often faced by pharmacists in providing drug information to patients. Among them, the working time of pharmacists in pharmacies is very limited with a hefty workload, especially in the morning to manage pharmacy administration, readiness as informers, and noncooperative attitudes of the patient. The reduction of pharmacist 
workload is related to timing to provide information and reducing dispensing errors (Shao et al., 2020). Other studies have shown community pharmacists were relatively less confident in their ability to communicate with patients and other health professionals (Hagemeier, Ventricelli and Sevak, 2017). By paying attention to the average time to deliver drug information, which does not reach two minutes, it can be determined that the information provided by the pharmacist is also limited. It is important to note that patient education is an important component in improving adherence to therapy and optimizing the use of drugs (Young, Tordoff and Smith, 2017). Naik Panvelkar, Saini and Armour (2009) state that the higher the frequency of counseling and monitoring and the more directions given, the greater the satisfaction rating derived.

The results also showed that pharmacists rarely did verification before handing over drugs to the prescription service. In self-medicated services, there were some pieces of information that were rarely extracted from patients (showing a frequency below $50 \%$ ), namely the age of the user, the gender of the user, the user's body weight, symptoms of the disease, and the possibility of other diseases/ special conditions. It can be said that pharmacist did not explore the patient's condition. In accordance with this information, Naughton (2018) states that pharmacists tend to explain or provide more in-depth education for patients without realizing that patient counseling may not be effective without adequate patient exploration of the patient's concerns, beliefs, attitudes, and behavior since the start of the consultation.

Quality indicators are used to improve community pharmacy practice (Alhusein and Watson, 2019). Patient satisfaction is an important indicator of the service quality provided for monitoring and improving the quality of health service delivery (Naik Panvelkar, Saini and Armour, 2009). Parasuraman, Zeithaml and Berry (1988) suggest there are five main sub-dimensions service quality. The service quality dimensions are adapted to suit pharmaceutical services to measure patient satisfaction with pharmaceutical services.

Tangible are physical features. The questionnaire given on the tangible dimension measured the patient's response to the physical condition of the pharmacy, including the cleanliness and proper waiting room. Patient satisfaction on the tangible dimension at outlet 1 was lower than outlet 2 . The difference was statistically significant. However, the satisfaction scores of the two dominant pharmacies were in the very poor category, which means that the two pharmacies have not been able to meet the patients' expectations within the tangible dimension. Physical facilities, equipment, and communication materials become important when the patient arrives depressed (S., R. and J., 2018). In line with the results found by Yulia, Baga and Djohar (2016), the performance that attributes to the five pharmaceuticals services dimensions at Depok City pharmacies was still considered to be below the respondents' expectations.

Reliability is the ability to perform the promised services reliably and accurately. The questionnaire given on the reliability dimension measured the patient's response to drug administration and the information provided at the time of drug administration. Patient satisfaction at outlet 1 and outlet 2 on the reliability dimension was statistically similar. Most of the respondents answered that the drugs had been delivered directly by the pharmacist. According to the results of the study, information on how to store drugs and the effects of therapy and drug side effects should be improved. The direct observation also showed the infrequent provision of this information.

Responsiveness is the ability to help customers and provide services quickly. The questionnaire given on the responsiveness dimension included the responsiveness of pharmacists in serving patients. Patient satisfaction for both outlets on the responsiveness dimension was not statistically significant. Most of the respondents thought that the pharmacist responsiveness in serving patients was still insufficient or very insufficient. 
Assurance is the knowledge and courtesy of employees and their ability to generate trust and confidence. The questionnaire on the assurance dimension included the appearance of the pharmacists, as well as the attitude and behavior of the pharmacists while serving the patients. In the assurance dimension, the value of customer satisfaction at outlet 1 and outlet 2 was statistically significant. Outlet 1 had a better assessment on the assurance dimension. The physical appearance of pharmacists, attitudes, and behavior of pharmacists while serving patients were considered to be significantly different between the two outlets.

Empathy is the willingness to care, pay attention to customers, be sensitive to consumer expectations, and always strive to meet consumer needs. The questionnaire on the empathy dimension included the pharmacist's ability to understand the patient in terms of explaining drug information in an easy-tounderstand way, giving the opportunity to ask questions, and the pharmacist's willingness to confirm the patient's condition. Outlet 1 had a better rating than outlet 2 on the empathy dimension, which was statistically significant different.

Empathy is a mental state that makes people feel or identify themselves in the same state of feeling or thought as other individuals or groups. To increase public trust, pharmacy workers must be able to show empathy for patients and be supported by the proper facilities of $a$ pharmacy (Antari, Meriyani and Suena, 2019), as well as the competence and confidence to encourage patients to be open (Allinson and Chaar, 2016). Problems related to the profession and professional attitudes require special attention, considering patient welfare is of utmost importance (Unhurian et al., 2018).

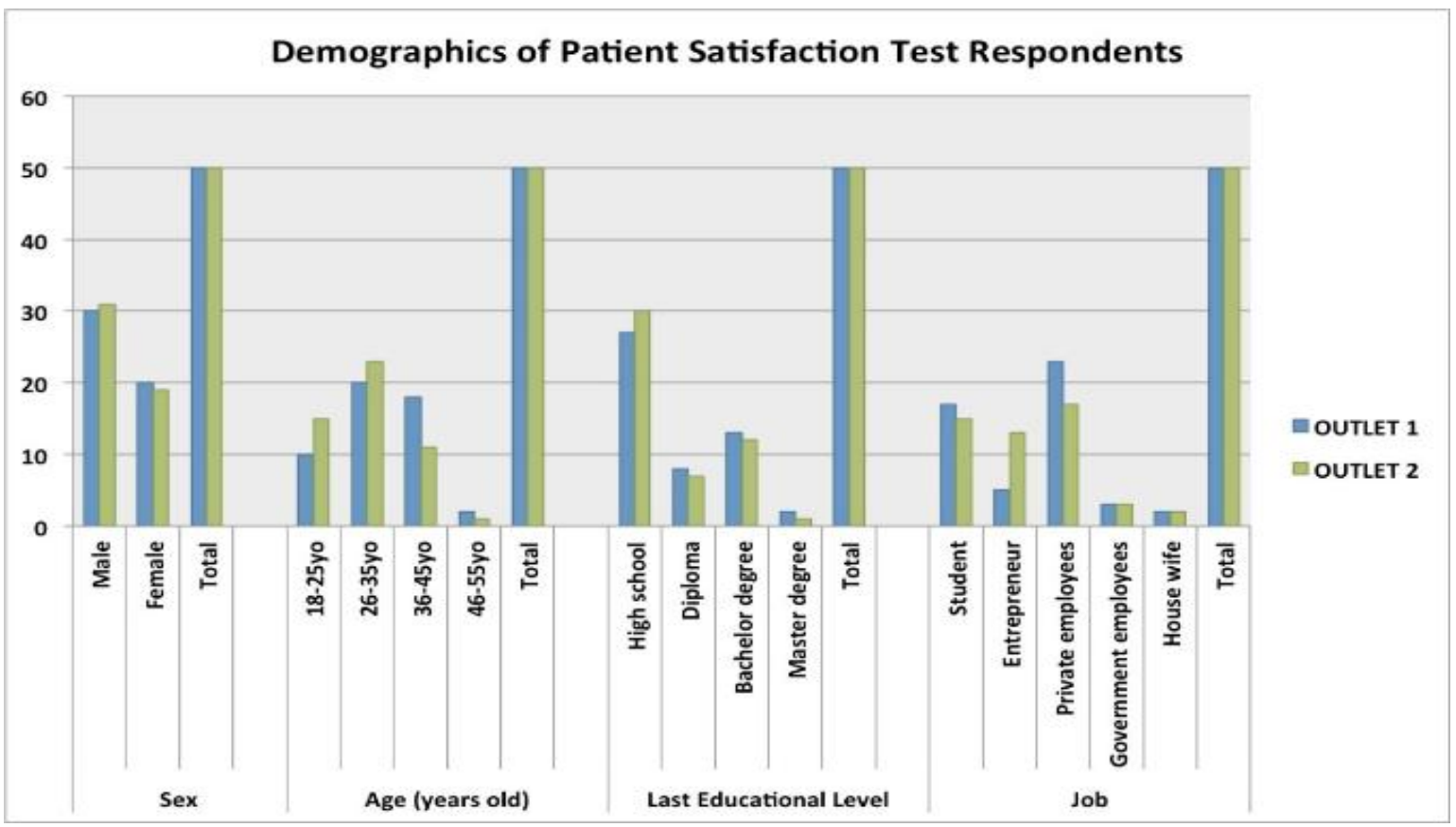

Figure 1. Respondents's demographic data according to patient satisfaction questionnaire 
Table 3. Results of Data Analysis on Patient Satisfaction at Outlet 1 and Outlet 2

\begin{tabular}{lccc}
\hline \multirow{2}{*}{$\begin{array}{c}\text { Satisfaction classification } \\
\text { per dimension }\end{array}$} & \multicolumn{2}{c}{ The value from the respondent } & Bivariate Analysis \\
\cline { 2 - 4 } Outlet 1 n(\%) & Outlet 2 n(\%) & (P-value) \\
\hline Tangible & & & $0.040^{*}$ \\
Very low & $48(96 \%)$ & $34(68 \%)$ & \\
Low & $2(4 \%)$ & $12(24 \%)$ & \\
Adequate & - & $4(8 \%)$ & \\
Good & - & - & $0.103^{* *}$ \\
Very good & - & - & \\
Reliability & & & \\
Very low & $5(10 \%)$ & $5(10 \%)$ & \\
Low & $8(16 \%)$ & $2(4 \%)$ & \\
Adequate & $5(10 \%)$ & $7(14 \%)$ & \\
Good & $15(30 \%)$ & $9(18 \%)$ & \\
Very good & $17(34 \%)$ & $27(54 \%)$ & \\
Responsiveness & & & \\
Very low & $34(68 \%)$ & $46(92 \%)$ & \\
Low & $15(30 \%)$ & $4(8 \%)$ & \\
Adequate & $1(2 \%)$ & - & \\
Good & - & - & \\
Very good & - & - & \\
Assurance & & & \\
Very low & $10(20 \%)$ & $23(46 \%)$ & \\
Low & $10(20 \%)$ & $9(18 \%)$ & \\
Adequate & $12(24 \%)$ & $7(14 \%)$ & \\
Good & $11(22 \%)$ & $10(20 \%)$ & \\
Very good & $7(14 \%)$ & $1(2 \%)$ & \\
Empathy & & & \\
Very low & $3(6 \%)$ & $11(22 \%)$ & \\
Low & $8(16 \%)$ & $13(26 \%)$ & \\
Adequate & $17(34 \%)$ & $10(20 \%)$ & \\
Good & $9(18 \%)$ & $12(24 \%)$ & \\
Very good & $13(26 \%)$ & $4(8 \%)$ & \\
\hline
\end{tabular}

* tested using the Mann Whitney test

** tested using the Chi-Square test

Figure 1 shows the demographic data of the respondents in the patient satisfaction test at outlet 1 and outlet 2 . Table 3 shows the results of the analysis of patient satisfaction with pharmaceutical services at outlet 1 and outlet 2 .

According to Dieleman, Gerretsen and van der Wilt (2009), inadequate performance of health workers is a very broad problem. Poor performance causes inappropriate services and contributes to decreased health outcomes. One of the factors that can support performance is communication skills, for which training is needed to improve pharmacist communication skills. Training on drug administrators has an influence on increasing knowledge of drug management and clinical pharmacy services (Amrullah, Satibi and Fudholi, 2020). According to Rowe et al. (2005), in low and middle-income countries, the role of health workers is very important in the delivery of health interventions. Trained pharmacists and assistant pharmacists play an important role in recommending over-the-counter drugs to first-time buyers (Emmerton and Shaw, 2002).

Service quality affects customer satisfaction and customer loyalty (Monica, Dharmmesta and Syahlani, 2017). Satisfied patients are more likely to continue to use health care services, value and maintain relationships with health care providers, adhere to treatment, and have better health outcomes (Naik Panvelkar, Saini and Armour, 2009). Satisfaction is the feeling of pleasure or disappointment 
in someone resulting from comparing the perception of the product received or outcomes associated with expectations (Kotler and Keller, 2006). Patients' expectations for the pharmaceutical services they receive are influenced by several factors, including information received by patients from the surrounding environment, previous experience of using the same services, and patient impressions of the service providers (Antari, Purnomo and Sumarni, 2011). In line with this, it is stated that an important factor that will help advance pharmaceutical services in any country is understanding the needs, expectations, and satisfaction of the community (Jose, Al Shukili and Jimmy, 2015).

A logistic regression test was used to identify the effect of each dimension simultaneously on sales turnover. The dimension that had the highest influence on sales turnover was empathy, followed by the reliability dimension, the responsiveness dimension, the assurance dimension, and the tangible dimension.

Public services, pharmacist attitudes, drug availability, convenience, pharmacy facilities, and location were found to have a very positive effect on patient satisfaction. Increased waiting time for prescription services consistently negatively affected patient satisfaction (Naik Panvelkar, Saini and Armour, 2009; S., R. and J., 2018). Research in Thailand has suggested that consumers' perceptions of pharmacists influenced consumer retention, positive word of mouth, and constructive suggestions to pharmacies, but the quality of the pharmacy structure and drug prices (Nitadpakorn, Farris and Kittisopee, 2017). A study in Japan has found that the domains of pharmaceutical service quality in society included adequate resources, professional expertise, and service policies and procedures (Sato et al., 2020). Satisfied consumers will make repeated purchases and even spread their satisfied impression to others. In addition, satisfaction also creates consumer loyalty to pharmacies resulting in more consumers coming to shop and increasing pharmacy sales turnover with increasing sales volume.
Assessment of employee work motivation and organizational culture at outlet 1 was carried out on 13 respondents, while assessment at outlet 2 was carried out on 9 respondents. Demographics of respondents can be seen in Figure 2. Based on demographics, employees at outlet 1 were mostly female, while employees at outlet 2 were mostly male. Employees at outlet 2 on average were still very young with a maximum age of 31 years, while employees at outlet 1 were with a maximum age of 37 years old. Only one employee at outlet 2 had worked there for more than five years, while at outlet 1 there were two people who had worked there for more than five years.

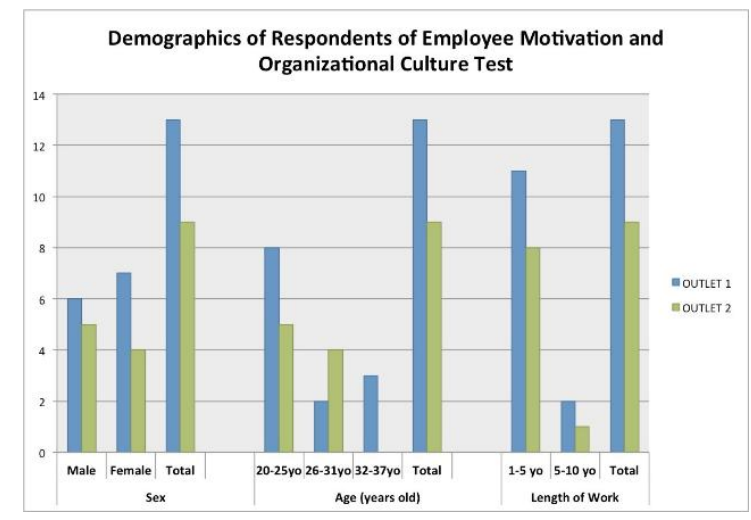

Figure 2. Demographic data of the respondents in the employee motivation and organizational culture test

Employee work motivation data was not normally distributed, thereby the test for differences in employee motivation between the two outlets was carried out using the Mann Whitney test. Median data at outlet 1 was $2.6(\min 2.4$; $\max 2.65)$ and median data at outlet 2 was 2.4 (min 2.25; max 2.6), and a p-value of 0.007 was obtained with a mean rank at outlet 2 of 7.28 and a mean rank at outlet 1 of 14.42 , thus it can be concluded that there is a significant difference in motivation between outlet 1 and outlet 2, with higher work motivation at outlet 1 compared to work motivation at outlet 2. According to the income of both pharmacies, Outlet 1 generated higher sales turnover compared to outlet 2. One of the factors that shape performance is employee motivation. Work motivation will shape performance 
and ultimately form the image of a health service location. According to Zaini, Satibi and Lazuardi (2014), satisfactory pharmacist service is one of the factors that influence consumer intention to use pharmaceutical services.

Employee at outlet 1 and outlet 2 have equal teamwork motivation. Outlet 1 superior at some dimensions of employee motivation such as: trust in the institution, best performance at work, and willingness to comply with role. Employee at outlet 1 have better trust in the institution regarding reward and punishment system. Seems that employee at outlet 1 satisfied with reward and punishment system so they have better motivatian to achieve the best performance and greater willingness to comply with the role in that organization. Work motivation is an impetus in someone to do a task or activity to the best of their abilities in order to attain high achievements (Anwarudin, Fudholi and Satibi, 2013). Researchers and theorists state that motivation can directly influence performance and mediate the influence of other factors. Thus, motivation and interventions that increase motivation and job satisfaction (including salary, prestige, and working conditions) tend to be important determinants (Rowe et al., 2005). Gardjito, Musadieq and Nurtjahjono (2014) stated similar results, who showed that work motivation has a significant effect on performance. High-quality service cannot be provided unless the problem of unmotivated staff is handled comprehensively (Willis-Shattuck et al., 2008). Work environment has a significant effect on motivation (Basuki and Maesaroh, 2017). One of the factors that can encourage increased productivity of human resources is efforts to increase adequate work motivation, such as meeting external needs (meeting primary needs, food, clothing, and shelter as well as adequate environment) and internal needs (the employee desire to place themself in a satisfying career position) (Gardjito, Musadieq and Nurtjahjono, 2014).

Performance in companies depends on the ability and environment as well as motivation (Uneputty, Masruchin and
Djoharsyah, 2017). Health worker motivation reflects the interaction between workers and their work environment (Franco et al., 2004). A comfortable, safe, and clean work environment will lead to or increase morale, and a bad work environment will reduce performance (Gardjito, Musadieq and Nurtjahjono, 2014). The work environment is largely shaped by organizational culture. Organizational culture is a set of assumptions or belief systems, values, and norms developed within the organization which serve as a code of conduct for its members to overcome problems of external adaptation and internal integrity (Widiati, 2012).

The median of the organizational culture at outlet 1 was 2.8 ( $\min 2.65$; max 2.9 ) and the median of the organizational culture at outlet 2 was 2.6 ( $\min 2.55$; max, 2.75). The data was not normally distributed, thereby the difference test of organizational culture between the two outlets was carried out using the Mann Whitney test. A p-value of $<0.001$ was obtained with the mean rank of outlet 1 at 15.31 and the mean rank of outlet 2 at 6.00 , thus it can be concluded that there is a significant difference in organizational culture between the two outlets. The organizational culture of outlet 1 was rated higher than the organizational culture at outlet 2. Outlet 1 shows better organizational culture at some dimensions namely: communication, reward and punishment system, problem solving, performance appraisal, opportunities for self-improvement, employee appreciation and role implementation. Role implementation was in line with employee motivation to comply with the role in that organization as well as reward and punishment system, and performance appraisal system.

The results are in accordance with the sales turnover of pharmacies. Pharmacies that had high sales turnover (outlet 1) had a better organizational culture than pharmacies that had low sales turnover (outlet 2).

Organizational culture is an internal factor that reflects the way employees do their jobs, such as making decisions and serving customers, which can be seen and 
felt by people outside of the organization (Jatiningrum, Musadieq and Prasetya, 2016). The type of organizational culture has a significant effect on employee performance (Asy'ari and Nurnida, 2018). The most influential factor on work productivity is organizational commitment, meaning that with high organizational commitment, employees will automatically work hard for the company, be proud of the company, and have a good emotional bond with the company (Kosasih, 2019).

In spite of the results stated earlier, this study has some limitations. The results of direct observation of pharmaceutical services are possibly bias. The art of communication to explore and convey information from each pharmacist cannot be well-described through the observation method using a checklist. Since the researcher only observed without interacting with the staff, the results of the observations were made without any attention to why such information was not extracted or given by the pharmacists to the patients. For example, dosage information was rarely given because the pharmacists thought that the dosage information had also been conveyed when they told the patients about how to use the drug (one tablet taken three times a day). The results showed that the pharmacists rarely conveyed precise weight or volume measurements, for example, $500 \mathrm{mg}$ paracetamol tablets or $5 \mathrm{~mL}$ paracetamol syrup. Patient verification was also no longer done. If there is only one patient waiting for a prescription, there is no need for verification. The limitations of pharmaceutical services found at the two outlets may be a general description of the implementation of pharmaceutical services in Indonesia, therefore a larger subject is needed to ensure this.

\section{Conclusion}

As the results of this study show, the pharmaceutical services at outlets with high sales turnover is different from pharmaceutical services at low sales turnover outlets. Based on the logistic regression test, the satisfaction dimension that had the highest effect on sales turnover involved empathy, followed by the reliability dimension, the responsiveness dimension, the assurance dimension, and the tangible dimension, which had the weakest influence. Outlets that have high sales turnover also have better organizational culture and higher employee motivation when compared to outlets that have low sales turnover.

\section{Abbreviations}

SPSS: Statistical Package for the Social Science; Min: Minimum; Max: Maximum; mg: miligram; $\mathrm{mL}$ : mililiter.

\section{Declarations}

Ethics Approval and Consent Participant Respondents were addressed before the survey about the survey's objectives and purposes, and verbal consent to participate in the study was taken from them.

\section{Conflict of Interest}

The authors declare that there are no significant competing financial, professional, or personal interests that might have affected the performance.

\section{Availability of Data and Materials}

Data and material research can be provided by upon request.

\section{Authors' Contribution}

NPUA conceptualized the study and created the methodology; NPUA, NPDA, and NMDSS wrote, reviewed, and edited the manuscript; NPUA and NMDSS wrote the original draft.

\section{Acknowledgment}

We would like to thank the Faculty of Pharmacy, Universitas Mahasaraswati Denpasar, for their technical support, and to the respondents in the Community Pharmacies and all the contributors who helped in this study. 


\section{References}

Alarussi, A. S. and Alhaderi, S. M. (2018) 'Factors affecting profitability in Malaysia', Journal of Economic Studies, 45(3), pp. 442-458. doi: 10.1108/JES-05-2017-0124.

Alhusein, N. and Watson, M. C. (2019) 'Quality indicators and community pharmacy services: a scoping review', International Journal of Pharmacy Practice, 27(6), pp. 490500. doi: 10.1111/ijpp.12561.

Allinson, M. and Chaar, B. (2016) 'How to build and maintain trust with patients', The Pharmaceutical Journal, 297(7895), pp. 300-303.

Amrullah, H., Satibi, S. and Fudholi, A. (2020) 'Pengaruh Pelatihan Pelayanan Kefarmasian terhadap Pengetahuan Pengelola Obat di Puskesmas Kabupaten Ogan Komering Ilir', Jurnal Manajemen dan Pelayanan Farmasi (Journal of Management and Pharmacy Practice), 10(1), pp. 45-55. doi: 10.22146/jmpf.50601.

Antari, N. P. U., Meriyani, H. and Suena, N. M. D. S. (2019) 'Faktor-Faktor Komunikasi yang Mempengaruhi Tingkat Kepercayaan terhadap Tenaga Teknis Kefarmasian', Jurnal IImiah Medicamento, 5(2), pp. 6369.

doi:

10.36733/medicamento.v5i2.431.

Antari, N. P. U., Purnomo, A. and Sumarni, S. (2011) 'Difference in Outpatient's Expectation and Perception toward Pharmacy Service of RSUP Dr. Sardjito Yogyakarta and Rumah Sakit Bethesda Yogyakarta', Jurnal Manajemen dan Pelayanan Farmasi, 1(2), pp. 84-88. doi: 10.22146/jmpf.35.

Anwarudin, W., Fudholi, A. and Satibi (2013) 'Evaluasi Kinerja Unit Bisnis Apotek Perusahaan Daerah Farmasi Ciremai Kota Cirebon Dengan Balanced Scorecard Sebagai Bahan Penyusunan Strategy Maps', Jurnal Manajemen dan Pelayanan Farmasi, 3(4), pp. 291-310. doi: 10.22146/jmpf.224.

Asy'ari, R. R. and Nurnida, I. (2018)
'Analisis Tipe Budaya Organisasi dan Pengaruhnya terhadap Kinerja Karyawan (Studi pada PT Kimia Farma Apotek Unit Bisnis Bandung)', Almana (Jurnal Manajemen dan Bisnis), 2(3), pp. 108-114. Available at: http://journal.unla.ac.id/index.php/al mana/article/view/157.

Athiyah, U. et al. (2019) 'Assessment of pharmacists' knowledge, attitude and practice in chain community pharmacies towards their current function and performance in Indonesia', Pharmacy Practice, 17(3), pp. 1-7. doi: 10.18549/PharmPract.2019.3.1518

Basuki, K. and Maesaroh, M. (2017) 'Motivasi Sebagai Pemediasi Pengaruh Komitmen Dan Lingkungan Kerja Pada Kepuasan Kerja', Business Management Journal, 13(1), pp. 1-15. doi: 10.30813/bmj.v13i1.254.

Castaldo, S. et al. (2016) 'The missing path to gain customers loyalty in pharmacy retail: The role of the store in developing satisfaction and trust', Research in Social and Administrative Pharmacy, 12(5), pp. 699-712. doi: 10.1016/j.sapharm.2015.10.001.

Dieleman, M., Gerretsen, B. and van der Wilt, G. J. (2009) 'Human resource management interventions to improve health workers' performance in low and middle income countries: A realist review', Health Research Policy and Systems, 7(7), pp. 1-13. doi: 10.1186/1478-4505-7-7.

Dung, L. T. (2019) 'Pharmacist's interaction behavior and consumer loyalty: The mediating role of consumer trust and satisfaction', Journal of Behavioral Science, 14(3), pp. 1-13.

Emmerton, L. and Shaw, J. (2002) 'The influence of pharmacy staff in nonprescription medicine sales', International Journal of Pharmacy Practice, 10(2), pp. 101-106. doi: 10.1111/j.20427174.2002.tb00594.x.

Franco, L. M. et al. (2004) 'Determinants 
and consequences of health worker motivation in hospitals in Jordan and Georgia', Social Science and Medicine, 58(2), pp. 343-355. doi: 10.1016/S0277-9536(03)00203-X.

Gardjito, A. H., Musadieq, M. Al and Nurtjahjono, G. E. (2014) 'Pengaruh Motivasi Kerja dan Lingkungan Kerja Terhadap Kinerja Pegawai', Jurnal Administrasi Bisnis, 13(1), pp. 1-8. doi: 10.17509/jimb.v2i1.13083.

Gunawan, R. et al. (2011) Tingkat Kehadiran Apoteker serta Pembelian Obat Keras tanpa Resep di Apotek. Denpasar.

Hagemeier, N. E., Ventricelli, D. and Sevak, R. J. (2017) 'Situational communication self-confidence among community pharmacists: A descriptive analysis', Research in Social and Administrative Pharmacy, 13(6), pp. 1175-1180. doi: 10.1016/j.sapharm.2016.12.003.

Hermansyah, A. et al. (2020) 'Primary health care policy and vision for community pharmacy and pharmacists in Indonesia', Pharmacy Practice, 18(3), p. 2085. doi:

10.18549/PharmPract.2020.3.2085

Hermansyah, A., Sainsbury, E. and Krass, I. (2018) 'Multiple policy approaches in improving community pharmacy practice: The case in Indonesia', BMC Health Services Research, 18(1), pp. 1-14. doi: 10.1186/s12913-018-3258-8.

Indonesian Ministry of Health (2016) Peraturan Menteri Kesehatan RI No 73 Tahun 2016 Tentang Standar Pelayanan Kefarmasian di Apotek, Kementerian Kesehatan Republik Indonesia.

Jatiningrum, C. D., Musadieq, M. Al and Prasetya, A. (2016) 'Pengaruh Budaya Organisasi, Motivasi dan Kemampuan terhadap Kinerja', Jurnal Administrasi Bisnis, 39(1), pp. 117-124.

Jawaid, S. A. (2016) 'Quality of pharmacy services and regulatory compliance', Pakistan Journal of Medical Sciences, 32(5), pp. 1063-1065. doi: 10.12669/pjms.325.11416.

Jaya, M. K. A. and Apsari, D. P. (2018)
'Gambaran Waktu Tunggu dan Identifikasi Faktor yang Mempengaruhi Lama Waktu Tunggu Pelayanan Obat atas Resep Dokter di Puskesmas Kota Denpasar', Jurnal IImiah Medicamento, 4(2), pp. 94-99. doi: 10.36733/medicamento.v4i2.861.

Jose, J., Al Shukili, M. N. and Jimmy, B. (2015) 'Public's perception and satisfaction on the roles and services provided by pharmacists Cross sectional survey in Sultanate of Oman', Saudi Pharmaceutical Journal, 23(6), pp. 635-641. doi: 10.1016/j.jsps.2015.02.003.

Kosasih (2019) 'Analisis Tentang Pengaruh Budaya Kerja, Komitmen Organisasi, Dan Standar Prosedur Operasional Terhadap Produktivitas Kerja Karyawan (Studi Kasus di PT Kimia Farma Apotek Tbk (Persero) Wilayah Bandung Timur)', JRBJurnal Riset Bisnis. doi: 10.35592/jrb.v1i2.245.

Kotler, P. and Keller, L. K. (2006) Marketing Management. 12th edn. New Jersey: Pearson Prentice Hall.

Kristina, S. A. R. I., Lienaningrum, A. S. and Aditama, H. (2021) 'Assessing Patient Satisfaction with Community Pharmacy Services in Yogyakarta, Indonesia', International Journal of Pharmaceutical Research, 13(01). doi: 10.31838/ijpr/2021.13.01.652.

Monica, E., Dharmmesta, B. S. and Syahlani, S. P. (2017) 'Correlation Analysis Between the Service Quality, Customer Satisfaction, and Customer Loyalty of Viva Generik Pharmacy In Semarang', Journal of Pharmaceutical Sciences and Community. doi: 10.24071/jpsc.142569.

Naik Panvelkar, P., Saini, B. and Armour, C. (2009) 'Measurement of patient satisfaction with community pharmacy services: a review', Pharmacy World \& Science, 31(5), pp. 525-537. doi: 10.1007/s11096009-9311-2.

Nasution, A. A. (2020) 'Effect of inventory turnover on the level of profitability', IOP Conference Series: Materials Science and Engineering, 725(1). 
doi:

$10.1088 / 1757-$

899X/725/1/012137.

Naughton, C. (2018) 'Patient-Centered Communication', Pharmacy, 6(1), p. 18. doi: 10.3390/pharmacy6010018.

Nitadpakorn, S., Farris, K. B. and Kittisopee, T. (2017) 'Factors affecting pharmacy engagement and pharmacy customer devotion in community pharmacy: A structural equation modeling approach', Pharmacy Practice, 15(3), pp. 1-8. doi:

10.18549/PharmPract.2017.03.999.

Novianita, M., Sutarsa, I. N. and Adiputra, I. N. (2016) 'Factors Associated with the Quality of Pharmacy Service Provision in Denpasar, Bali', Public Health and Preventive Medicine Archive, 4(1), pp. 42-47. doi: 10.15562/phpma.v4i1.55.

Parasuraman, A., Zeithaml, A. V. and Berry, L. L. (1988) 'Servqual: A multiple-item scale for measuring consumer perceptions of Service Quality', Journal of Retailing, 64(1), pp. 2-40.

Rabbanee, F. K., Burford, O. and Ramaseshan, B. (2015) 'Does employee performance affect customer loyalty in pharmacy services?', Journal of Service Theory and Practice, 25(6), pp. 725743. doi: 10.1108/JSTP-06-20140126.

Rizal, R., Romidon, H. and Handika, I. (2017) 'Analisis Bauran Pemasaran terhadap Omzet Penjualan pada PT. Gaudi Dwi Laras Cabang Palembang', Jurnal Adminika, 3(2), pp. 78-94.

Rowe, A. K. et al. (2005) 'How can we achieve and maintain high-quality performance of health workers in low-resource settings?', Lancet, 366(9490), pp. 1026-1035. doi: 10.1016/S0140-6736(05)67028-6.

S., K., R., S. W. A. and J., S. G. A. (2018) 'Patients' Satisfaction towards the Service Quality of pharmacy in the Government Hospitals in Sri Lanka', Management Issues, 3(I). Available at:

https://www.ou.ac.Ik/home/images/F aculty_and_institute/MS/FMS_E_Ne
ws/Management Issues volume 3 2018.pdf.

Salem, K. Y. et al. (2020) 'The influence of professional pharmacist services on pharmacy service quality of pharmacies in Kupang city, East Nusa Tenggara province, Indonesia', International Journal Of Community Medicine And Public Health, 7(12), p. 4760. doi: 10.18203/2394-

6040.ijcmph20205147.

Satibi, S., Furdiyanti, H. N. and Rahmawati, M. (2007) 'Performance evaluation of pharmacy $x$ in Yogyakarta using balanced scorecard approach', Indonesian Journal of Pharmacy, 18(2), pp. 7180. doi: 10.14499/indonesianjpharm0iss0pp 71-80.

Sato, N. et al. (2020) 'Exploring the factors influencing the quality of "Health Support Pharmacy" services in Japan: Perspectives of community pharmacists', Research in Social and Administrative Pharmacy, (February), pp. 1-8. doi: 10.1016/j.sapharm.2020.02.012.

Shao, S. C. et al. (2020) 'Workload of pharmacists and the performance of pharmacy services', PLOS ONE, 15(4), pp. 1-12. doi: 10.1371/journal.pone.0231482.

Uneputty, J. P., Masruchin and Djoharsyah (2017) 'Pengaruh Kondisi Kerja dan Budaya Kerja terhadap Kinerja Karyawan dengan Motivasi Kerja sebagai Variabel Intervening (Studi pada Tenaga Kefarmasian PT. Kimia Farma Apotek Unit Bisnis Manado)', Pharmacon (Jurnal IImiah Farmasi), 6(4), pp. 266-275.

Unhurian, L. et al. (2018) 'Implementation of Standards of Good pharmacy practice in the World: A Review', Asian Journal of Pharmaceutics, 12(1), pp. 42-46.

Watson, M. C. and Skea, Z. C. (2018) 'Jugglers and tightrope walkers: The challenge of delivering quality community pharmacy services', PLoS ONE, 13(7), pp. 1-15. doi: 10.1371/journal.pone.0200610. 
Widiati, E. (2012) 'Pengaruh Motivasi Kerja, Disiplin Kerja Dan Budaya Organisasi terhadap Kinerja Pegawai Kesehatan Pada Rumah Sakit Panti Secanti Gisting', Jurnal Magister Manajemen, 1(1), pp. 109143.

Willis-Shattuck, M. et al. (2008) 'Motivation and retention of health workers in developing countries: A systematic review', BMC Health Services Research, 8, pp. 1-8. doi: 10.1186/1472-6963-8-247.

Young, A., Tordoff, J. and Smith, A. (2017) "What do patients want?" Tailoring medicines information to meet patients' needs', Research in Social and Administrative Pharmacy, 13(6), pp.

1186-1190.

doi:

10.1016/j.sapharm.2016.10.006.

Yulia, P. R., Baga, L. M. and Djohar, S. (2016) 'Kepuasan Konsumen terhadap Pelayanan Apotek dan Tingkat Pengetahuan Konsumen Mengenai Standar Pelayanan Kefarmasian yang Berlaku (Studi Kasus di Kota Depok)', Jurnal Aplikasi Bisnis dan Manajemen, 2(3), pp. 312-322. doi: 10.17358/JABM.2.3.312.

Zaini, M., Satibi and Lazuardi, L. (2014) 'Analysis of Consumer Intention in Utilization of Pharmacy Service', Jurnal Manajemen dan Pelayanan Farmasi, 4, pp. 17-24. 